\title{
Soil Loss Assessment Using the Revised Universal Soil Loss Equation (RUSLE) Model
}

\author{
Allois Luvai $\mathbb{D}$, ${ }^{1}$ John Obiero $\mathbb{D}^{2},{ }^{2}$ and Christian Omuto $\mathbb{D}^{2}$ \\ ${ }^{1}$ Pwani University, School of Agricultural Sciences and Agribusiness, Kilifi, Kenya \\ ${ }^{2}$ University of Nairobi, Faculty of Engineering, Nairobi, Kenya \\ Correspondence should be addressed to Allois Luvai; kioko.allois@gmail.com
}

Received 15 December 2021; Accepted 20 January 2022; Published 15 February 2022

Academic Editor: Fedor Lisetskii

Copyright (c) 2022 Allois Luvai et al. This is an open access article distributed under the Creative Commons Attribution License, which permits unrestricted use, distribution, and reproduction in any medium, provided the original work is properly cited.

Many catchment areas have suffered from exhaustive changes because of various land use activities over the recent past. These land use changes are associated with intensified environmental degradation witnessed in catchment areas. Such environmental problems include extreme soil erosion. Soil erosion is one of the most critical problems responsible for the degradation of land worldwide. This phenomenon occurs as a result of the complex interactions that exist between natural and human-induced factors. Most factors experience spatiotemporal variations, hence complicating the soil erosion phenomenon. This complexity in the erosion process makes it difficult to quantify soil loss. Without proper information on soil loss, it becomes quite hard for decision-makers and managers to manage catchment areas. However, the availability of soil erosion models has made it easy to estimate soil loss. Many models have been developed to consider these complexities in soil erosion studies. Empirical models such as RUSLE provide a simple and broad methodology through which soil erosion is assessed. The RUSLE model integrates well geographic information system (GIS) and above all remote sensing. This paper presents an overview of the developmental milestones in estimating soil loss using the RUSLE model. The parameterization of the RUSLE model has been adequately reviewed with much emphasis on challenges and successes in derivation of each individual factor. From the review, it was established that different equations have been developed by researchers for modeling the five factors for the RUSLE model. The development of such equations was found to take into account the different variations that depict the soil erosion process.

\section{Introduction}

Land is undoubted the most essential natural resource, which is crucial in sustaining livelihoods in most subSaharan African countries. Most human activities relate directly and/or indirectly to land resources [1]. Development agendas in these SSA countries are pegged on prudent use of vital land resources. However, deterioration of land resources has been identified as a major drawback to such developmental milestones [2]. Land degradation is described as a perennial problem that has posed serious threats to food security in many developing countries all over the world. Land is quite a complex medium that is highly variable, and above all, it is prone to degradation threats such as erosion, low organic matter, landslides, and contamination [3]. On this basis, researchers have defined land degradation as reduction in the production potential of land due to depleted fertile soils, important soil biodiversity, and natural resources.

Drastic increase in soil erosion was noted throughout the twentieth century in various parts of the world [4-6]. Historical documentation on the perception of soil erosion is lacking, although researchers have argued that the phenomenon is largely prehistoric [7]. Soil erosion has been singled out as the worst type of land degradation, especially in Africa and Asian countries [8]. Land degradation has been identified as the most extensive environmental threat in many developing countries [8-11]. Panagos et al. [12] referred to soil erosion as a land degradation process whose impacts affect food production, biodiversity, carbon stocks, and ecosystem services. Agricultural lands have been immensely degraded by soil erosion where the top fertile layer 
has been lost, increased runoff, and low availability of water to plants $[5,13,14]$. Research has shown that soil erosion has so far led to the degradation of agricultural lands to a tune of nearly 80 percent [4]. It is reported that nearly 2 billion hectares of land have already been degraded, and this translates to about 12 to 15 tonnes of soil per hectare per year [15]. Morgan [16] reported that agricultural lands worldwide lose about 22 to 100 ton $\mathrm{ha}^{-1} \mathrm{yr}^{-1}$ of topsoil, translating to an annual productivity decline of about 15 to 30 percent. Morgan [16] further quantified that about 30 to 44 billion US dollars are spent on soil erosion-related effects.

Land resources have become quite fragile, and as such, considerations targeted for adaptation and mitigation are critical requirements. Natural threats such as severe droughts, soil erosion dynamics, flash floods, and pollution have subjected land resources to unnecessary pressure. Natural processes contribute to soil loss, especially in soil erosion form. Soil erosion is exacerbated by anthropogenic activities such as human settlement agricultural production and mining activities. For these reasons, many nations have prioritized the attainment of food security and the creation of a sustainable environment by putting in measures to reverse soil erosion-related impacts [17]. Therefore, the basic success for soil conservation plans is to quantify soil loss in critically affected areas and most importantly to identify the best management application [14]. Thus, quantifying the magnitude of soil erosion in addition to its spatial distribution would help in minimizing the problems associated with soil erosion $[5,18]$. At catchment scales, the determination of soil erosion is quite challenging because of the heterogeneity of the catchment due to the different biophysical factors. Catchments experience variability in hydrological regimes at different spatiotemporal scales hence complicating soil erosion dynamics $[5,19,20]$. This challenge can be overcome by the use of models because they provide a reasonable way of estimating soil erosion. Different soil erosion models have the capability to simulate various aspects of the soil erosion process [21, 22]. However, models are chosen based on the objectives, scale, data availability, and support facilities.

\section{Soil Erosion Process}

Soil erosion is a quite complex phenomenon that is governed by some natural processes where the end result is decreased soil fertility, depleted water quality, and above all reduced crop yields [14, 23]. Biophysical factors that comprise soil, climate, ground cover, terrain, and their interactions modify the soil erosion process [14]. Terrain characteristics that affect soil erosion include slope gradient, slope length, aspect, and shape [24]. The runoff mechanism is greatly influenced by the slope gradient impact and aspect. As the slope gradient increases, the infiltration component reduces, and the generated runoff runs down the slope, the end result is more erosion.

Soil erosion is described as a natural geomorphic (both endogenic and exogenic) process whose occurrence on the land's surface is quite continuous, and above all, it is more frequent and well distributed [25]. This is because the surface of the Earth is exposed to water, wind, ice action, and gravitational forces at various spatiotemporal scales [26]. Soil erosion process is accelerated by anthropogenic perturbations and improper land use practices, whose impacts are felt on soil and environment [24]. Farming, habitation, terracing, deforestation, and overgrazing are some of the activities which lead to increased soil erosion rates. Soil erosion process has three distinct phases: detachability, transportability, and deposition [27-29]. Soil erosion process begins with detachment, where breakdown of soil particles occurs due to raindrop impact, shearing, and/or the drag force possessed by wind or even through forces that result from tillage activities [24, 30-32]. Detached soil particles are transported and thereafter get deposited as the force of the eroding agent subsides.

Water-induced soil erosion is reported to be the most extensive among the other soil erosion causes [33]. This form of erosion is much dependent on land cover, surface gradient, and type of soil. Water erosion has a significant contribution to depletion of organic matter content and important soil nutrients; hence, the functionality of the soil is largely affected. According to Pimentel [34], farmlands are washed at a rate of between 10 and 40 tonnes, which is much more than the rate of soil replacement. Water erosion has been identified as a worldwide problem because of the interrelationship between natural resources, population, and climate change. A study by Lal [35] reported that about 1094 Mha of global land had been affected by water erosion, out of which 751 Mha had suffered extreme deterioration.

\section{Soil Erosion Models}

Soil erosion models make use of mathematical expressions so as to relate dominant parameters and processes that occur on land's surface [36]. The parameters involved include terrain characteristics, soil properties, land use/land cover, and weather variables $[36,39]$. Soil erosion models describe detachment, transport, and deposition phases, which comprise the soil erosion process [38, 39]. Soil erosion models serve as important tools for planning because they enable the prediction of soil loss [40]. Above all, models create a clear understanding of the entire soil erosion phenomenon and the resulting impacts [40]. However, the choice of appropriate models for a particular soil erosion study is based on the objectives, catchment characteristics, and data availability on the model's efficiency [41]. Consequently, models differ based on complexity, involved processes, and data required to calibrate and use the model [39]. It is argued that a model cannot be applied practically in all scenarios, and as such, the best ideal model would depend on the planned use and catchment characteristics under consideration [39]. Other factors determining the model's choice as highlighted by Merritt et al. [39] include model's data requirements (including model's spatiotemporal variation of input and out data), model's accuracy and validity, not forgetting any underlying assumptions, model capabilities as defined by its components, user's objectives (ease of use, model scales, and the form of output), and model's hardware requirements. Generally, soil erosion 
models have been categorized into three types based on the physical processes to be simulated, algorithms that describe such processes, and data dependence by the model $[39,39,42]$.

3.1. Physically Based Models. Physically based models have wide applications in soil erosion modeling [24]. Physical models evolved faster due to the increased urge to understand how better hydrological processes could be represented and above all availability of field level measurement techniques [43]. Physical models are known to describe a catchment's soil erosion process by providing solutions to fundamental physics equations $[28,39]$. Chandramohan et al. [44] noted that physical models were in a position to predict runoff and even sediment yield on a spatial basis for an individual storm.

Morgan [45] referred to physically based models as process-based models since they model soil erosion using an empirical approach. These models rely on specific differential equations referred to as the continuity equation commonly theorized as the law of conservation of matter through space in a given time frame $[16,26]$. Physical models have the power to synthesize soil erosion components, way of interactions, and temporal variability [46]. However, physical models do not optimize parameter sets [24], and despite being complex, they require huge amounts of data [42]. Further, physical models that have been designed and developed for use in small areas cannot be used to model larger catchments [24]. Physical models have been widely applied by different researchers to study water quality problems and erosion processes [42]. The following physical models have been developed and applied in different parts of the world: European Soil Erosion Model (EUROSEM) [47], Areal Nonpoint Source Watershed Environment Response Simulation model (ANSWERS) [48], Water Erosion Prediction Project model (WEPP) [49], Griffith University Erosion System Template model (GUEST) [50], and Productivity, Erosion and Runoff, Functions to Evaluate Conservation Techniques model (PERFECT) [51].

3.2. Empirical Models. This category of soil erosion models utilize inductive logic, some experiences, and results from an experiment and have the advantage that they are quite simple in their use $[39,52]$. Empirical models have wide application because of the fewer computations involved and the fewer amount of data required $[39,53,54]$. They model the amount of detached soil by use of mathematical equations to link objectively measured parameters such as slope gradient, basin area, and parameters that require subjective assigning such as soil erodibility factor. These models do not seek to explain the physics behind erosion processes in catchments, and therefore, they are validated based on a region and its underlying conditions [3].

The assumption that input data is quite homogenous throughout the entire basin area forms the basis for the development of empirical models. To this end, reliable results are obtained upon application of this category of models in limited extent areas where the variability of the parameters of interest is quite negligible $[39,53]$. The input data is assumed to be constant throughout the period of analysis. However, empirical models are quite expensive in addition to being involved especially during calibration exercise where much time is required to obtain the much needed data. Moreover, detailed experiments are necessary so as to collect important data to facilitate calibration. Some common examples include Universal Soil Loss Equation (USLE) [55], Modified Universal Soil Loss Equation (MUSLE) [56], sediment delivery ratio (SDR) [57], Agricultural Nonpoint Pollution Source (AGNPS) [57], Sediment Delivery Distributed (SEDD) [58], and Revised Universal Soil Loss Equation (RUSLE) [60].

3.3. Conceptual Models. Conceptual models typically represent a catchment like a string of internal storage [39]. Such models define the broad mechanisms behind the interchange of water and sediment between these storages [39]. Sediment-producing parameters, notably rainfall and runoff, serve as the system's input and sediment yield as the output [44]. However, Sujatha and Sridhar [42] pointed out that parameters used in conceptual models have limited scope when it comes to interpretation of physical processes involving sediment yield and also soil erosion. Here, underlying transfer mechanisms that involve generation of sediment and runoff are incorporated in the model where flow paths within the catchment are represented as storages in a series form where the dynamic behavior of each requires some characterization [39]. Some good examples of conceptual models include Chemical Runoff and Erosion from the Agricultural Management Systems (CREAMS) model [61] and Large Scale Catchment Model (LASCAM) [62].

3.4. Model Scales. Evidence has shown that most soil erosion parameters depend on scales at varying degrees [63]. Soil erosion processes experience spatiotemporal variation due to interactions of the many factors involved at each scale $[3,64]$. According to Ciesiolka and Rose [65], studies carried out on smaller geographical extents tend to have emphasized on-site soil erosion impacts, while those done on larger geographical extents concentrated on off-site impacts. Therefore, erosion models must consider the spatiotemporal effects of the catchment [66]. Incorporating a model in erosion studies describes the process of soil erosion and the mechanism of sediment transport at different spatiotemporal scales [67]. Both runoff and soil erosion rates experience spatiotemporal variation, and therefore, it is quite important to define the model scales, processes, and factors involved [68]. According to Karydas et al. [63], models are developed to operate at some specified spatial extent and time frame, both of which describe the spatial and temporal scales.

Hill slopes and catchment areas (small, medium, and large) define spatial scales $[66,69]$. In terms of land areas the spatial scales correspond to $<0.1 \mathrm{~km}^{2}, 0.1 \mathrm{~km}^{2}, 1,000 \mathrm{~km}^{2}$, $1,000 \mathrm{~km}^{2}, 10,000 \mathrm{~km}^{2}$, and more than $10,000 \mathrm{~km}^{2}$, respectively [69]. Owens and Collins [66] reported that erosion processes and sediment transport increase with an increase 
in spatial scales. A spatiotemporal continuum (Figure 1) gives an overview of the water erosion phenomenon at different spatiotemporal scales, processes, forms of water erosion, and features involved [63]. On this basis, it is prudent enough to develop important datasets that would help in soil erosion modeling and in understanding sediment transport. Karydas et al. [63] reported that geospatial properties such as spatiotemporal and spatial methodologies form an important platform for modeling soil erosion.

\section{RUSLE Model}

RUSLE model is a good example of an empirical model which is well recognized, widely accepted and very much implemented in soil erosion studies [60, 70, 71]. It is derived from the USLE model, and its application spans to over 40 years $[60,72]$. The model was designed and developed by a team of high-ranking scientists and some soil conservationists having vast experience in matters relating to soil erosion [4]. It comprises mathematical equations that quantify the average soil loss on an annual basis at different geospatial scales [73, 74]. According to Renard et al. [60], this is the best technology ever for estimation of soil loss in undisturbed areas characterized by overland flow, land surface experiencing disturbance and recently or already reclaimed lands. Additionally, the model is very well applicable in ungauged catchments, its demand for data is quite moderate, and above all, it integrates well with GIS enabling upscaling of the soil erosion process [74].

The results of the RUSLE model are a representation of the sediment amount lost from a user-defined landscape [73]. The superiority of the model is brought about by its prowess in accounting for different control management actions with minimal data requirements [42]. The basic assumption that forms the foundation of the RUSLE model is that detachability and deposition processes are a function of sediment content [14]. It is argued that until sediment load attains threshold capacity, soil detachment cannot occur [42]. Therefore, the process of soil erosion is influenced by the flow carrying capacity and not by its source [42].

Recent breakthroughs in spatial information technologies have augmented the prevailing methods in monitoring, analyzing, and above all managing resources [63]. The spatial variation of soil erosion risk is brought about by heterogeneity in topography, geomorphology, geology, land cover, soil types, and land use. Such spatial variability of soil erosion parameters is easily and efficiently handled by geographic information systems (GIS) [75]. This trend has improved the accuracy, costs, and scales of application [76]. The state-of-the-art technology geographic information system provides essential mapping interpolation techniques for creating a database that comprises input datasets for modeling soil erosion [75]. Management of large datasets is made easier with the use of GIS; therefore, such spatial techniques provide a basis for the management of land upon the estimation of soil loss rates [75]. In RUSLE, soil loss is predicted by converting the input data (rainfall data, soil data, digital elevation model, and land use) into a

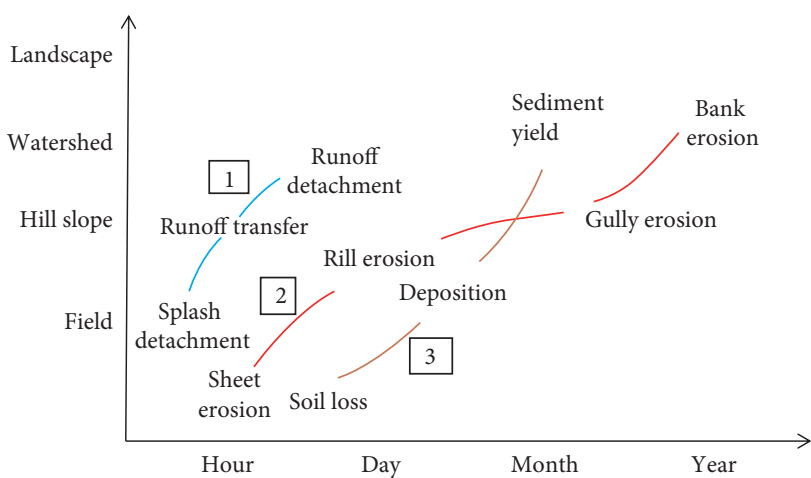

FIGURE 1: Spatiotemporal continuum: erosion processes (1), forms (2), and features (3) (source: [63]).

geographical information system format, following which it is implemented in the geospatial framework [42].

Many researchers worldwide have adopted this methodology to carry out soil erosion studies at different spatial scales. For instance, the following researchers studied soil loss in catchment areas by applying the RUSLE model, GIS, and remote sensing $[18,33,42,53,54,70,72,77-84]$. The studies revealed that, apart from estimating soil erosion, the methodology was found to be satisfactory in identifying areas that had higher soil erosion risks. Further, geospatial tools facilitated the extraction of important information, which was deemed critical in implementing plans for soil conservation [85].

4.1. RUSLE Model Parameterization. The model quantifies average annual soil loss $(A)$ using five important factors, notably rainfall erosivity $(R)$, soil erodibility $(K)$, slope length and slope steepness (LS), cover management (C), and support practice $(P)$.

$$
A=R \times K \times L S \times C \times P,
$$

where $A$ is the mean annual soil loss in $\mathrm{tha}^{-1} \mathrm{yr}^{-1}, R$ is the rainfall erosivity ( $\left.\mathrm{MJ} \mathrm{mm} \mathrm{ha} \mathrm{mrr}^{-1}\right), K$ is the soil erodibility factor ( $\mathrm{thahha}{ }^{-1} \mathrm{MJ}^{-1} \mathrm{~mm}^{-1}$ ), LS is the slope length and slope steepness factor (dimensionless), $C$ is the cover management factor (dimensionless), and $P$ is the support practice factor (dimensionless).

4.1.1. Rainfall Erosivity Factor ( $R$ ). Rainfall is a precondition for any form of water erosion to materialize [86]. The amount and even intensity of rainfall are the two important attributes for rainfall [87]. Waterborne erosion is more pronounced when the two rainfall attributes are on the higher side [86]. Rainfall erosivity factor $(R)$ quantifies the erosive power possessed by rainfall, and it much depends on the rainfall's intensity and amount $[29,60,86]$. The $R$ factor is expressed as the sum of EI-values for each particular storm for a year and averaged for over long periods of time (more than 20 years) so as to accommodate discernible recurring rainfall patterns [29]. The abbreviation EI refers to the product of energy and maximum intensity of rainfall in 30 minutes [87]. The amount of soil loss is proportional to 
TABLE 1: The $R$ factor algorithms.

\begin{tabular}{lccc}
\hline Equation & Area of application & Researcher(s) & Serial number \\
\hline$R=0.55 \mathrm{MAR}-24.7$ & Ethiopia and Egypt & Hurni [88] \\
$R=-8.12+0.562 \mathrm{MAR}$ & Ethiopia & Hurni [88] & Singh et al. [89] \\
$R=79+0.363 \mathrm{MAR}$ & Entire India & Singh and Phadke [90] \\
$R=50+0.389 \mathrm{MSR}$ & Entire India & Babu et al. [91] \\
$R=0.1059 \mathrm{abc}+52$ & Dehradun, India & $\mathbf{4}$ \\
$R=22.8+0.6400 \mathrm{MAR}$ & Ivory Coast and Burkina Faso & Roose [92]; Morgan [93] \\
$R=0.5 \mathrm{MAR}$ & Northern Jordan & Eltaif et al. [94] \\
$R=23.61 e^{0.0048 \mathrm{MAR}}$ & Kenya & Kassam et al. [95] & $\mathbf{7}$ \\
$R=117.6\left(1.00105^{\mathrm{MAR}}\right)$ for $<2000 \mathrm{~mm}$ & Thailand & Harper [96] & $\mathbf{9}$ \\
$R=0.38+0.35 \mathrm{MAR}$ & Indonesia & Bols [97] & $\mathbf{1 0}$ \\
$R=2.5 P^{2} / 100(0.073 P+0.73)$ & $\mathbf{1 1}$ & $\mathbf{1 2}$ \\
\hline
\end{tabular}

MAR, MSR, and $P$ refer to mean annual rainfall $(\mathrm{mm})$, mean seasonal rainfall $(\mathrm{mm})$, and annual rainfall (mm), respectively. $a$ is the average annual rainfall $(\mathrm{mm}), b$ is the maximum 24-hour rainfall $(\mathrm{mm})$, and $c$ is the maximum 1-hour rainfall whose recurrence interval is 2 years.

the product of the total storm's energy, $E\left(\mathrm{MJ} \mathrm{ha}^{-1}\right)$, and the storm's maximum intensity in a time of $30 \mathrm{~min}, \mathrm{I}_{30}\left(\mathrm{mmh}^{-1}\right)$. The resulting product is known as the EI30 index or commonly as the storm erosivity index expressed in $\mathrm{MJ} m \mathrm{mha}^{-1} \mathrm{~h}^{-1}$. The storm erosivity index reflects the amalgamated effect of soil particle dislodgement and runoff transportability to cause net erosion [29]. The mean of the annual sums for the period under consideration gives the rainfall erosivity factor ( $R$ factor). Different researchers have developed equations from which the $R$ factor has been derived and applied in different regions (Table 1).

4.1.2. Soil Erodibility Factor (K). Different soils show varying degrees of resistance to water-related erosion [86]. Soil erodibility is an essential requirement when estimating soil loss and also when implementing soil conservation activities [71]. The characteristics of soil and its properties have a pronounced influence on soil erosion [70]. This effect is well represented by the soil erodibility factor [70]. Hence, the $K$ factor is affected by a variety of the soil's physicochemical properties [86].

The $K$ factor is simply defined as the inherent susceptibility of soil to soil erosion [72]. The RUSLE model identifies the distribution of particle size, permeability, organic matter content, and structure of the soil as the critical physicochemical properties which affect erodibility $[70,86]$. Quantitative determination of physicochemical properties of soils is carried out using conventional procedures in laboratories. Generally, soils that have low silt levels have less erodibility regardless of high fractions of both sand and clay [71]. Different $K$ factor algorithms have been developed and applied based on suitability and requirement (Table 2).

4.1.3. Slope Length and Slope Steepness (LS) Factor. The slope length $(L)$ and slope steepness $(S)$ define the landscape's topography, which mostly influence the extent of soil erosion [83]. $L$ and $S$ are the two most important parameters with regard to soil erosion modeling and most importantly when calculating the transporting power of surface runoff $[14,106]$. The LS factor therefore combines the effects of slope length and slope steepness, both of which account for the landscape's topographical effects on erosion
$[42,70,106]$. Hence, terrain effects on erosion processes are accounted for by the LS factor within the RUSLE model [107]. Soil erosion is noted to increase when both the slope angle and length increase [39]. This explains the sensitivity of terrain effects on soil erosion, and therefore determination of the LS factor needs to be accurate [71, 86].

The $L$ factor expresses the effect of the length of the slope on soil erosion [106]. The slope length is defined as the cumulative distance from the point at which runoff starts up to where the surface runoff reaches a well-defined channel $[14,79,108]$. From the definition of slope length, the amount of soil that is lost from a given area of land increases as the slope length increases $[14,106]$. The slope gradient factor expresses the effect of the steepness of the slope on soil erosion $[14,106]$. The slope gradient's effect on soil erosion is much more compared to that brought about by slope length $[14,106]$. This is an indication that soil erosion is much more pronounced especially in highly sloping areas $[84,86]$. Research has shown that soil erosion is disastrous in slopes ranging between 10 and 25\% [14]. However, the effect of slope gradient on soil erosion is countered by vegetation cover and the soil's particle size [106].

Different researchers have developed various equations for the derivation of the LS factor (Table 3). The equations are commonly based on the digital elevation model (DEM). Additionally, remote sensing technology has provided a substitute source of data where topographic-related details are provided [86]. With regard to the RUSLE model, the digital elevation model serves as an important input parameter where the variation of topographic features on a given landscape is quantitatively represented [86].

4.1.4. Cover Management Factor (C). Vegetation cover ranks second behind terrain effects in influencing soil erosion rate [113]. The parameters that define vegetation cover are mainly ground cover and plant canopy cover, respectively. Spatial distribution of vegetation cover fraction requires accurate estimation and is of utmost importance in soil erosion matters [113]. Vegetation cover prevents the soil from the impact of raindrops by dissipating the amount of energy they possess before reaching the soil surface $[71,114]$. Moreover, vegetation cover intercepts rainfall, thereby 


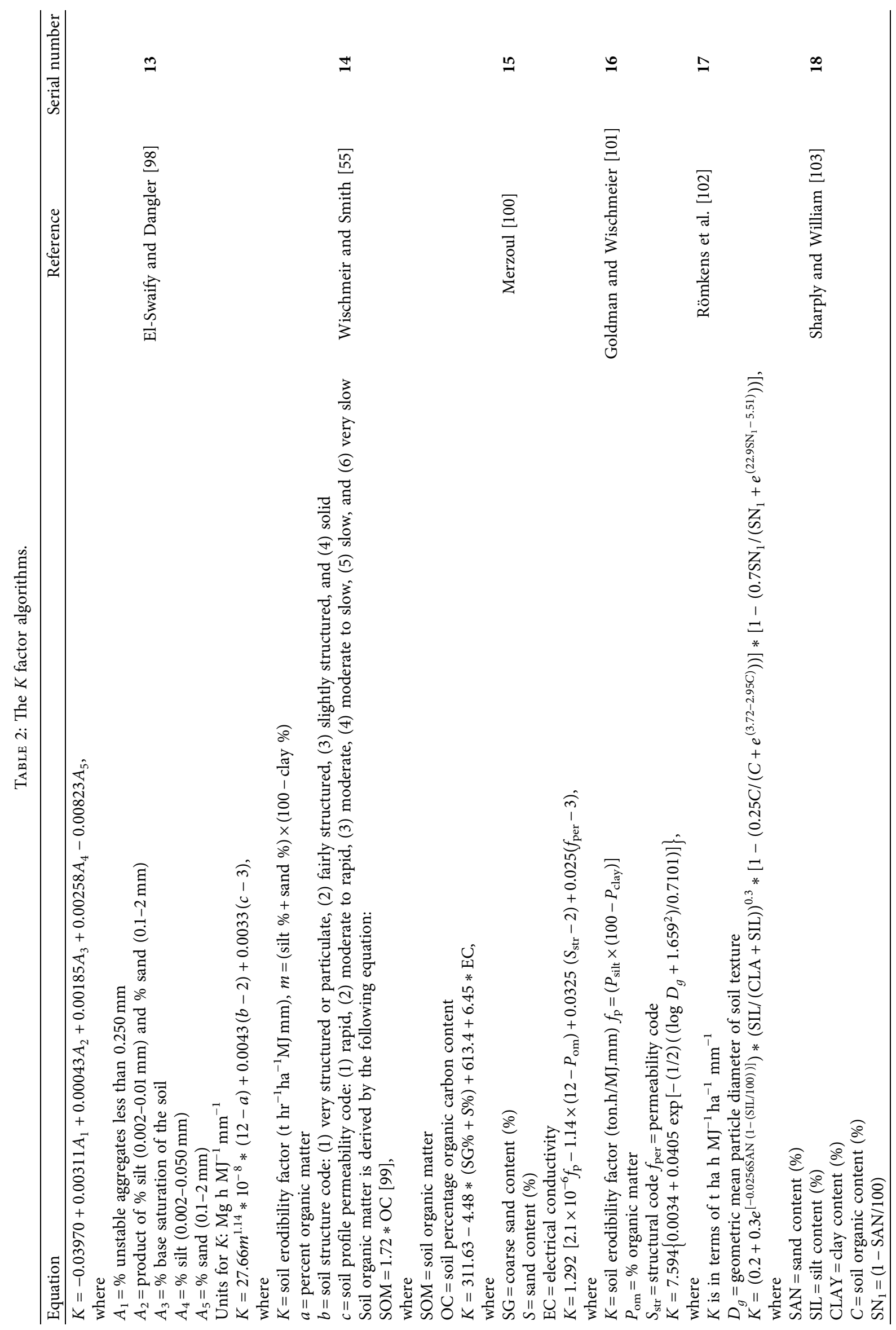




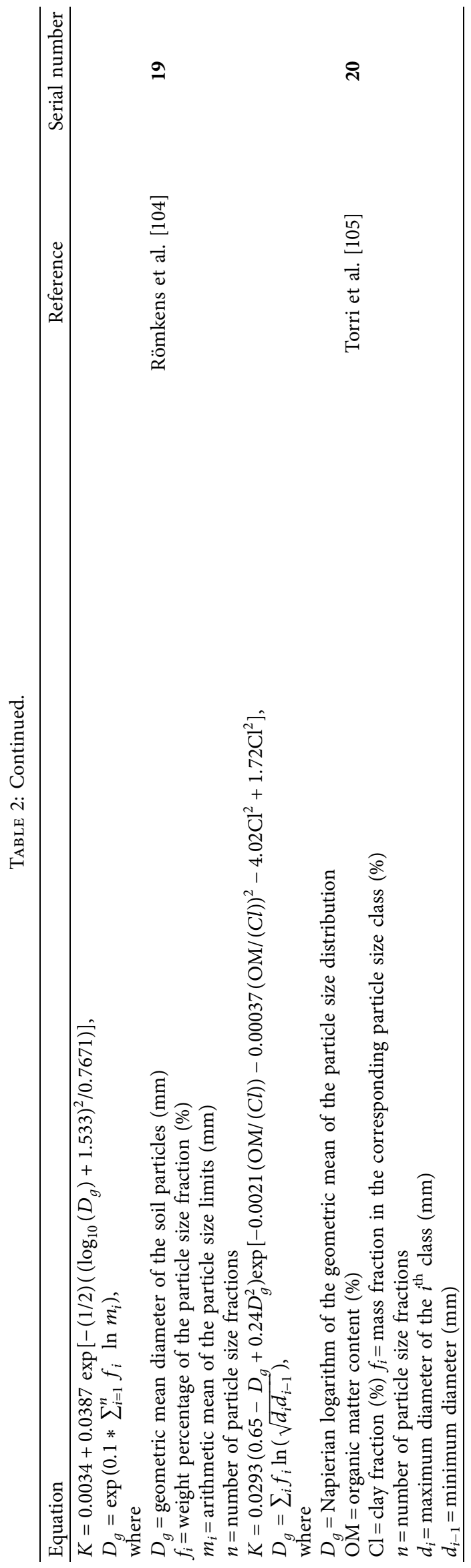


TABLE 3: LS factor algorithms.

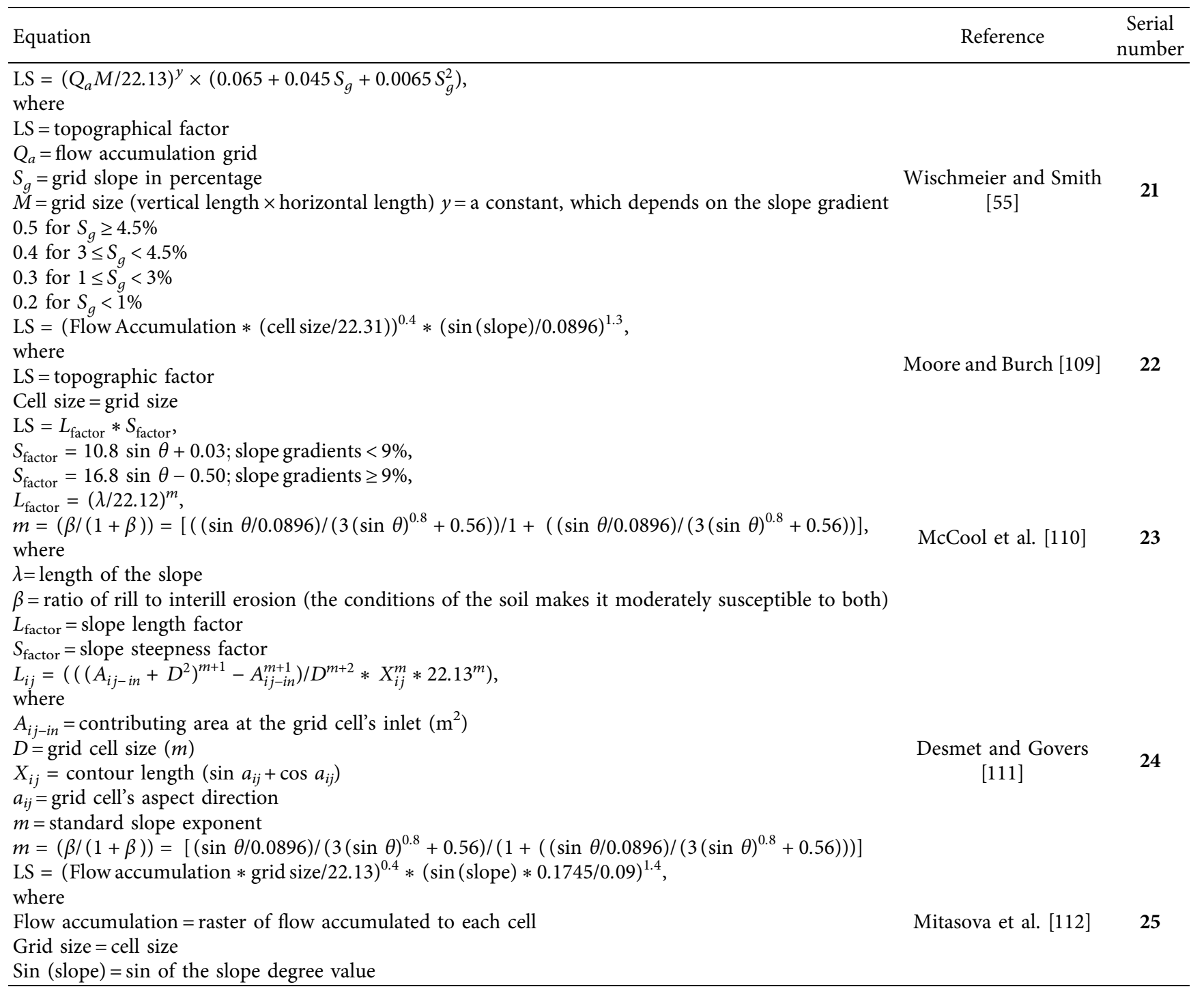

encouraging more infiltration. In the RUSLE model, vegetation cover effects are accounted for by the cover management factor $(C)$. The $C$ factor is defined as the ratio of soil lost from cropped land under specified conditions to that lost from bare soil [55]. It is much influenced by vegetation type, growth stage, and percent cover [113,115]. The crop management factor is indicative of the influence of vegetation cover and specified management practices on soil erosion $[60,106]$. The values have a range of between 0 and 1 depending on land cover types $[14,80]$. $C$ factor strongly relates to vegetation cover because it can be influenced by human beings to reduce erosion [116]. The $C$ factor is derived based on prior land uses, canopy shading factor, percent soil cover by crop remains, soil surface roughness, and above all soil moisture [60].

Within the RUSLE model, the crop management factor is calculated using some empirical relationships that contain ground cover information $[55,60]$. Satellite image information is an important input in the preparation of land cover maps, and as such, it has become an integral component in natural resources management. Traditionally, the $C$ factor values have been spatially estimated by assigning values to land cover classes identified using remote sensing [114]. Researchers have developed numerous methods for estimating the $C$ factor based on normalized difference vegetation index (NDVI) for assessment of soil loss using the RUSLE model (Table 4) [117]. These methods make use of regression analysis to establish the correlation between $\mathrm{C}$ factor values (obtained from fieldwork or from developed guide tables) and NDVI values obtained from remote sensing images [114]. The regression equations (linear/ nonlinear) are generated by correlating NDVI values with corresponding $C$ factor values.

4.1.5. Support Practice Factor $(P)$. Support practice $(P)$ factor is regarded as one of the most uncertain factors of the RUSLE model [122]. The support practice factor relates strongly to cover management factor because both reflect positive impacts resulting from management interventions in controlling 
TABLE 4: $C$ factor algorithms.

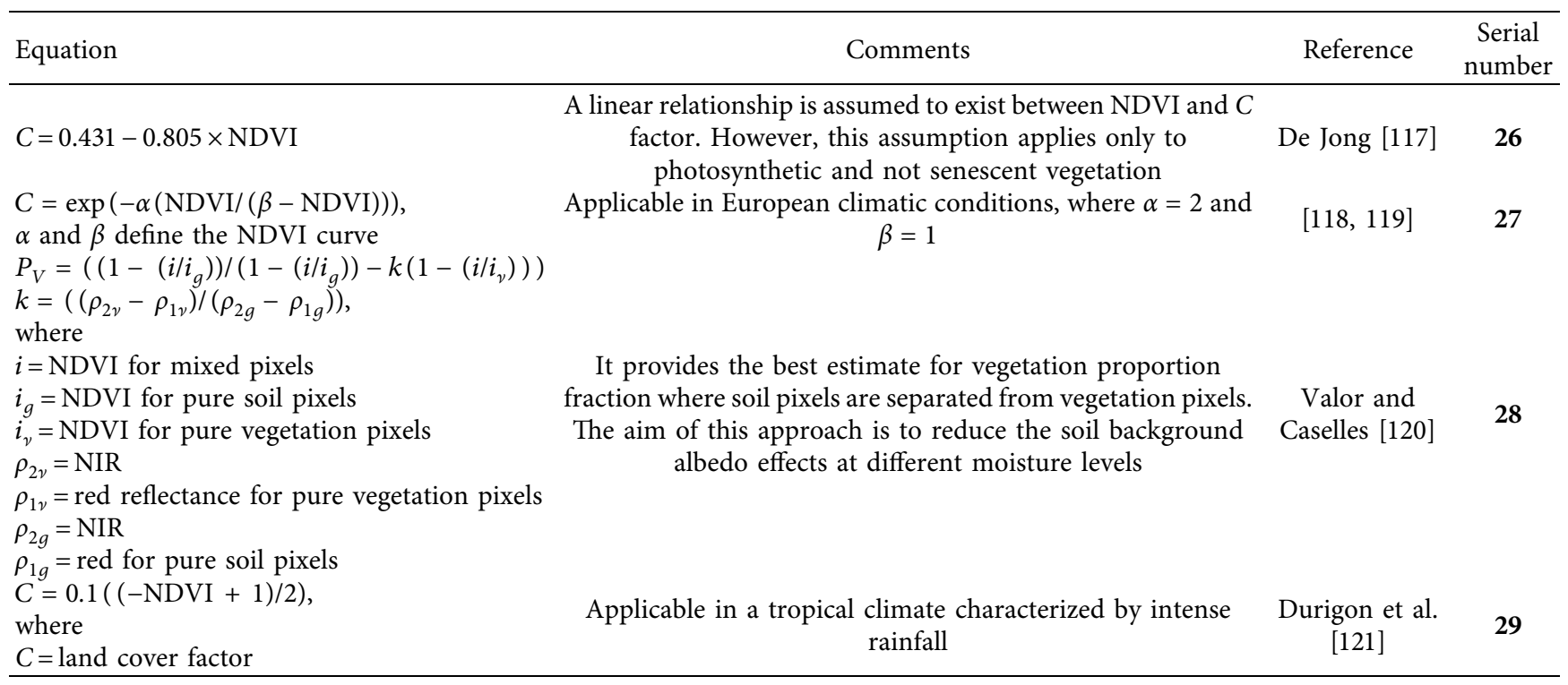

soil erosion [123]. The two factors differ in that the support practice factor quantifies the effects of some implementation that targets reducing the runoff and eventual soil loss [71]. The most common support practices include the use of contours, terraces, crop strips, grassed waterways, and cross-slope cultivation $[30,60,124]$. The $P$ factor is expressed as the ratio between the rate and the amount of soil lost when a specific support practice is used and similar soil loss when row farming is executed in an up- and downslope manner $[39,125]$. Typical $P$ factor values range between 0 and 1 . A value of 1 corresponds to lands without any support practice (especially grasslands and bare lands), while values which approach 0 are indicative of lands under specified support practices $[106,113]$. Lower $P$ factor values are indicative of effectiveness in conservation practices [107].

$P$ factor values are either derived from classified remotely sensed images, previous studies, or expert knowledge [12]. Just like the $C$ factor, the commonest approach for estimating $P$ factor values has been the use of field observation data and visually interpreted images [86]. The latter has played a crucial role in the assessment of agricultural management practices because it provides better spatial details [86]. However, it is argued that estimation of the $P$ factor using visually interpreted images is a tedious process, and to some extent, it lacks objectivity [86]. Ghosal and Bhattacharya [71] argued that the development of the support practice factor has not yet been elaborate up to date because many researchers have continued to rely on Wischmeier and Smith [55] concept. Wischmeier and Smith [55] tabulated $P$ factor values by considering different types of support practices, namely, contouring, terracing, and strip cropping. Researchers have applied such tabulations in different regions without any arising difficulties [71]. Two considerations have been proposed by Hurni et al. [126] for the calculation of the $P$ factor value. The first approach is based on conservation practice, while the second combines the topographical effects of the watershed and land use/land
TABLE 5: $P$ factor values for watershed conservation practices.

\begin{tabular}{lcc}
\hline Land use type & Slope $(\%)$ & $P$ factor \\
\hline Cultivated land & $0-5$ & 0.10 \\
& $5-10$ & 0.12 \\
$10-20$ & 0.14 \\
& $20-30$ & 0.19 \\
& $30-50$ & 0.25 \\
Other lands & $50-100$ & 0.33 \\
\hline
\end{tabular}

covers. Several researchers have used the second approach (Table 5), where land use and land cover are categorized as either cultivated or other land use types [108, 127-129]. This approach is used based on the fundamental assumption that soil and water conservation techniques are well practiced on cultivated land [108].

Empirical models have helped in predicting the $P$ factor in large catchments. However, they are limited to areas in which they have been developed [67]. One such equation was developed by Wener [130]. Equation (2) is an empirical equation that gives a linear relationship between the ground slope $(S)$ and the $P$ factor value.

$$
P=0.2+0.03 \times S,
$$

where $S$ is the percent slope.

Different researchers have computed the $P$ factor using equation (2) [131-133]. However, the accuracy of results obtained from the empirical equation depended on quality and even spatial resolution of the digital elevation model defining the slope map [86]. The applicable use of equation (2) in different environmental situations worldwide is not universal, and therefore, it is important to exercise caution when applying the same in different parts of the world [86]. In the event the equation is applied in the computation of the $P$ factor, the results must be compared with those obtained using different approaches. 


\section{Summary and Conclusions}

Soil erosion is a global threat to the environment, and its consequences are much felt in developing countries. Assessment of soil erosion is hindered by a lack of quality data and heterogeneity of environmental parameters. The review proves that the RUSLE model implemented in a geospatial environment is more efficient in soil loss studies. Adoption of the RUSLE model requires large data sets such as rainfall, soil, topography, land use, land cover, and land management. Further, creating a database using conventional techniques is a tedious process that, despite being timeconsuming, is quite difficult to manage. Thus, the geographic information system (GIS) is an important tool for estimating and predicting soil erosion risk. Geospatial techniques help in creating thematic layers of the five factors of the RUSLE model. Thereafter, the factors are overlaid in a geospatial environment to give a spatial variation of soil loss. Hence, objective results may be achieved with the right selection of satellite imagery indices, digital elevation models (DEM), and the correct methodology. The GIS-based approach of soil erosion assessment helps in minimizing subjective errors that are associated with classical estimations. On the contrary, this approach is helpful in maximizing the possibilities for diverse uses and even spatial computation.

\section{Data Availability}

All the data used to support the findings of this study are included within the paper.

\section{Conflicts of Interest}

The authors declare that they have no conflicts of interest.

\section{Acknowledgments}

The study was funded under a Ph.D. scholarship program provided by the Ministry of Agriculture, Livestock, Fisheries and Cooperatives through the Kenya Climate Smart Agriculture Project (KCSAP), which is funded by the World Bank.

\section{References}

[1] B. Jiang, Y. Bamutaze, and P. Pilesjö, "Climate change and land degradation in Africa: a case study in the Mount Elgon region, Uganda," Geo-Spatial Information Science, vol. 17, no. 1, pp. 39-53, 2014.

[2] V. Balabathina, R. P. Raju, and M. Wuletaw, "Integrated remote sensing and GIS-based universal soil loss equation for soil erosion estimation in the Megech river catchment, tana lake sub-basin, north western Ethiopia," American Journal of Geographic Information System, vol. 8, no. 4, pp. 141-157, 2019.

[3] M. Gianinetto, M. Aiello, F. Polinelli et al., "D-RUSLE: a dynamic model to estimate potential soil erosion with satellite time series in the Italian Alps," European Journal of Remote Sensing, vol. 52, no. sup4, pp. 34-53, 2019.

[4] S. D. Angima, D. E. Stott, M. K. O'Neill, C. K. Ong, and G. A. Weesies, "Soil erosion prediction using RUSLE for central Kenyan highland conditions," Agriculture, Ecosystems \& Environment, vol. 97, no. 1-3, pp. 295-308, 2003.

[5] O. J. Onyando, P. Kisoyan, and M. C. Chemilil, "Estimation of potential soil erosion for river perkerra catchment in Kenya," Water Resources Mangement, vol. 19, pp. 133-143, 2005.

[6] B. G. Jahun, R. Ibrahim, S. N. Dlamini, and M. S. Musa, "Review of soil erosion assessment using RUSLE model and GIS," Journal of Biology, Agriculture and Healthcare, vol. 5, no. 9, pp. 36-47, 2015.

[7] G. Hassen and A. Bantider, "Assessment of drivers and dynamics of gully erosion in case of Tabota Koromo and Koromo Danshe watersheds, South Central Ethiopia," Geoenvironmental Disasters, vol. 7, no. 5, 2020.

[8] S. Y. Kebede, T. N. Endalamaw, G. B. Sinshaw, and B. H. Atinkut, "Modeling soil erosion using RUSLE and GIS at watershed level in the upper beles, Ethiopia," Environmental Challenges, vol. 2, Article ID 100009, 2021.

[9] G. Girmay, A. Moges, and A. Muluneh, "Estimation of soil loss rate using the USLE model for Agewmariayam Watershed, northern Ethiopia," Agriculture \& Food Security, vol. 9, no. 9, 2020.

[10] N. Depountis, M. Vidali, K. Kavoura, and N. Sabatakakis, "Soil erosion prediction at the water reservoir's basin of Pineios dam, Western Greece, using the Revised Universal Soil Loss Equation (RUSLE) and GIS," WSEAS Transactions on Environment and Development, vol. 14, pp. 457-463, 2018.

[11] M. Y. Tessema, J. Jasinska, T. L. Yadeta, M. Switoniak, R. Puchalka, and G. E. Gebregeorgis, "Soil loss estimation for conservation planning in the welmel watershed of the genale dawa basin, Ethiopia," Agronomy, vol. 10, no. 777, 2020.

[12] P. Panagos, P. Borrelli, J. Poesen et al., "The new assessment of soil loss by water erosion in Europe," Environmental Science \& Policy, vol. 54, pp. 438-447, 2015.

[13] S. G. Ongwenyi, M. S. Kithiia, and O. F. Denga, "An overview of the soil erosion and sedimentation problems in Kenya," in Proceedings of the Yokohama Symposium Sediment Problems: Strategies for Monitoring, Prediction and Control, IAHS Publ, Yokohama, Japan, July 1993.

[14] P. B. Ganasri and H. Ramesh, "Assessment of soil erosion by RUSLE model using remote sensing and GIS-a case study of Nethravathi Basin. China University of Geosciences (Beijing)," Geoscience Frontiers, vol. 7, pp. 953-961, 2016.

[15] C. D. Biggelaar, R. Lal, K. Wiebe, and V. Breneman, "The global impact of soil erosion on productivity: absolute and relativity erosion-induced yield losses," Advances in Agronomy, vol. 81, pp. 1-48, 2003.

[16] R. P. C. Morgan, Soil Erosion and Conservation, Blackwell Publishing, Malden, MA, USA, 3rd edition, 2005.

[17] W. Bewket and E. Teferi, "Assessment of soil erosion hazard and prioritization for treatment at the watershed level: case study in the Chemoga Watershed, Blue Nile Basin, Ethiopia," Land Degradation \& Development, vol. 20, pp. 609-622, 2009.

[18] A. S. Bhat, I. Hamid, D. M. Dar, D. Rasool, A. B. Pandit, and S. Khan, "Soil erosion modeling using RUSLE \& GIS on micro watershed of J\&K," Journal of Pharmacognosy and Phytochemistry, vol. 6, no. 5, pp. 838-842, 2017.

[19] A. S. Kovacs, B. Fulop, and M. Honti, "Detection of hot spots of soil erosion and reservoir siltation in ungauged Mediterranean catchments," Energy Procedia, vol. 18, pp. 934-943, 2012.

[20] P. Panagos, C. Ballabio, P. Borrelli et al., "Rainfall erosivity in europe," The Science of the Total Environment, vol. 511, pp. 801-814, 2018. 
[21] BM. Mati, R. P. C. Morgan, and J. N. Quinton, "Soil erosion modelling with EUROSEM at Embori and Mukogodo catchments, Kenya," Earth Surface Processes and Landforms, vol. 31, pp. 579-588, 2006.

[22] Y. Hategekimana, M. Allam, Q. Meng, Y. Nie, and E. Mohamed, "Quantification of soil losses along the coastal protected areas in Kenya," Land, vol. 9, no. 137, 2020.

[23] A. Pandey, S. K. Himanshu, S. K. Mishra, and V. P. Singh, "Physically based soil erosion and sediment yield models revisited," Catena, vol. 147, pp. 595-620, 2016.

[24] N. B. Malleswara Rao, V. N. Umamahesh, and T. G. Reddy, "GIS-based soil erosion modelling for conservation planning of watersheds," ISH Journal of Hydraulic Engineering, vol. 11, no. 3, pp. 11-23, 2005.

[25] B. Ustun, "Soil erosion modelling by using GIS \& remote sensing: a case study, ganos mountain," The International Archives of the Photogrammetry, Remote Sensing and Spatial Information Sciences, vol. 37, no. 7, pp. 1681-1684, 2008.

[26] H. Mitasova, M. Barton, J. Hofierka, and R. S. Harmon, "GISbased soil erosion modelling," in Treatise on Geomorphology: Remote Sensing and GIScience in Geomorphology, vol. 3, pp. 228-258, Academic Press, San Diego, CA, USA, 2013.

[27] K. S. Jain, S. Kumar, and J. Varghese, "Estimation of soil erosion for a Himalayan watershed using GIS technique," Water Resources Management, vol. 15, pp. 41-54, 2001.

[28] R. M. Roshani, A. Rangavar, R. M. Javadi, and A. Ziyaee, "A new mathematical model for estimation of soil erosion," International Research Journal of Applied and Basic Sciences, vol. 5, no. 4, pp. 491-495, 2013.

[29] M. Tsitsagi, A. Berdzenishvili, and M. Gugeshashvili, "Spatial and temporal variations of rainfall-runoff erosivity (R) factor in Kakheti, Georgia," Annals of Agrarian Science, vol. 16, pp. 226-235, 2018.

[30] L. May and C. Place, "A GIS-based model of soil erosion and transport," Freshwater Forum, vol. 23, pp. 48-61, 2005.

[31] A. Sahu, T. Baghel, K. M. Sinha, I. Ahmad, and K. M. Verma, "Soil erosion modelling using RUSLE and GIS on dudhawa catchment," International Journal of Applied Environmental Sciences, vol. 12, no. 6, pp. 1147-1158, 2017.

[32] K. S. Tamang, W. Song, X. Fang, J. Vasconcelos, and B. Anderson, "Framework for quantifying flow and sediment yield to diagnose and solve the aggradation problem of an ungauged catchment," Proceedings of the IAHS, vol. 379, pp. 131-138, 2018.

[33] S. R. Thlakma, E. O. Iguisi, A. C. Odunze, and D. N. Jeb, "Estimation of soil erosion risk in mubi south watershed, Adamawa state, Nigeria," Journal of Remote Sensing \& GIS, vol. 7, pp. 1-10, 2018.

[34] D. Pimentel, A. Marklein, M. A. Toth et al., "Food versus biofuels: environmental and economic costs," Human Ecology, vol. 37, no. 1, pp. 1-12, 2009.

[35] R. Lal, "Soil erosion and global carbon budget," Environment International, vol. 29, no. 4, pp. 437-450, 2003.

[36] V. Jetten, G. Govers, and R. Hessel, "Erosion models: quality of spatial predictions," Hydrological Processes, vol. 17, pp. 887-900, 2003.

[37] P. C. Devatha, V. Deshpande, and S. M. Renukaprasad, "Estimation of soil loss using USLE model for Kulhan Watershed, Chattisgarh-a case study," Aquatic Procedia, vol. 4, pp. 1429-1436, 2015.

[38] M. A. Nearing, L. J. Lane, and V. L. Lopes, "Modelling soil erosion," Soil Erosion: Research Methods, pp. 127-156, 1994.
[39] S. W. Merritt, A. R. Letcher, and J. A. Jakeman, "A review of erosion and sediment transport models," Environmental Modelling \& Software, vol. 18, pp. 761-799, 2003.

[40] R. Benavidez, B. Jackson, D. Maxwell, and K. Norton, "A review of the (Revised) Universal Soil Loss Equation (R) USLE): with a view to increasing its global applicability and improving soil loss estimates," Hydrology and Earth System Sciences, vol. 22, pp. 6059-6086, 2018.

[41] S. D. Keesstra, A. J. A. M. Temme, J. M. Schoorl, and S. M. Visser, "Evaluating the hydrological component of the new catchment-scale sediment delivery model LAPSUS-D," Geomorphology, vol. 212, pp. 97-107, 2014.

[42] R. E. Sujatha and V. Sridhar, "Spatial prediction of erosion risk of a small mountainous watershed using RUSLE: a casestudy of the palar sub-watershed in kodaikanal, south India," Water, vol. 10, pp. 1-17, 2018.

[43] R. Ramsankaran, U. C. Kothyari, S. K. Ghosh, A. Malcherek, and K. Murugesan, "Physically-based distributed soil erosion and sediment yield model (DREAM) for simulating individual storms," Hydrological Sciences Journal, vol. 58, no. 4, pp. 872-891, 2013.

[44] T. Chandramohan, B. Venkatesh, and A. N. Balchand, "Evaluation of three soil erosion models for small watershed. International conference on water resources, coastal and ocean engineering (ICWRCOE)," Aquatic Procedia, vol. 4, pp. 1227-1234, 2015.

[45] R. Morgan, Soil Erosion and Conservation, Longman, Harlow, UK, 2nd edition, 1995.

[46] C. J. Ascough, C. D. Flanagan, J. Tatarko, A. M. Nearing, and H. Kipka, "Soil erosion modeling and conservation planning. Precision conservation: geospatial techniques for agricultural and natural resources conservation," Agronomy Monograph, vol. 59, 2017.

[47] R. P. C. Morgan, N. J. Quinton, E. R. Smith et al., "The European soil erosion model (EUROSEM): a dynamic approach for predicting sediment transport from fields and small catchments," Earth Surface Processes and Landforms, vol. 23, pp. 527-544, 1998.

[48] D. B. Beasley, F. L. Huggins, and E. J. Monke, "ANSWERS: a model for watershed planning," Transactions of the ASAE, vol. 23, no. 4, pp. 938-944, 1980.

[49] J. M. Laflen, J. L. Lane, and R. G. Foster, "WEPP, a next generation of erosion prediction technology," Journal of Soil Water Conservation, vol. 46, no. 1, pp. 34-38, 1991.

[50] R. K. Misra and C. W. Rose, "Applica-tion and sensitivity analysis of process-based erosion model GUEST," European Journal of Soil Science, vol. 47, pp. 593-604, 1996.

[51] M. Littleboy, M. D. Silburn, D. M. Freebaim, R. D. Woodruff, G. L. Hammer, and J. K. Leslie, "Impact of soil erosion on production in cropping systems, I. Development and validation of a simulation model," Australian Journal of Soil Research, vol. 30, pp. 757-774, 1992.

[52] I. A. Ayinla and C. A. Jona, "Prediction and estimation of sediments discharge from kangimi dam reservoir catchment, Kaduna, Nigeria," Universal Journal of Environmental Research and Technology, vol. 7, no. 1, pp. 19-37, 2018.

[53] N. Efthimiou, E. Lykoudi, and C. Karavitis, "Soil erosion assessment using the RUSLE model and GIS," European Water, vol. 47, pp. 15-30, 2014.

[54] H. Asadi, M. Honarmand, M. Vazifedoust, and A. Mousavi, "Assessment of changes in soil erosion risk using RUSLE in navrood watershed, Iran," Journal of Agricultural Science and Technology A, vol. 19, pp. 231-244, 2017. 
[55] W. H. Wieschmeier and D. D. Smith, "Predicting rainfall erosion losses-a guide to conservation planning," Series: Agriculture Handbook (3-4), USDA, Washington, DC, USA, 1978.

[56] J. R. Williams and H. D. Berndt, "Sediment yield prediction based on watershed hydrology," Transactions of the American Society of Agricultural Engineers, vol. 20, no. 6, pp. 1100-1104, 1977.

[57] R. A. Young, C. A. Onstad, D. D. Bosch, and W. P. Anderson, "AGNPS: a non-point source pollution model for evaluating agricultural watersheds," Journal of Soil and Water Conservation, vol. 44, no. 2, pp. 168-173, 1989.

[58] V. Ferro and P. Porto, "Sediment delivery distributed (SEDD) model," Journal of Hydrologic Engineering, vol. 5, pp. 411-422, 2000.

[59] W. G. Renfro, "Use of erosion equation and sediment delivery ratios for predicting sediment yield," Present and Prospective Tecnology for Predicting Sediment Yields and Sources, pp. 33-45, US Dept. Agric, Publ. ARS-S-40, Washington, DC, USA, 1975.

[60] K. Renard, G. Foster, G. Weesies, D. Mc Cool, and D. Yoder, Predicting Soil Erosion by Water: A Guide to Conservation Planning with the Revised Universal Soil Loss Equation (RUSLE), USDA Agriculture Handbook No. 703. United States Government Printing Office, Washington, DC, USA, 1997.

[61] G. W. Knisel, "CREAMS: a field-scale model for chemicals, runoff and erosion from agricultural management systems," USDA Conservation Research Report, vol. 26, no. 1, pp. 3664, 1980.

[62] N. R. Viney and M. Sivapalan, "A conceptual model of sediment transport: application to the Avon River Basin in Western Australia," Hydrological Processes, vol. 13, pp. 727-743, 1999.

[63] G. C. Karydas, P. Panagos, and Z. I. Gitas, "A classification of water erosion models according to their geospatial characteristics," International Journal of Digital Earth, vol. 7, no. 3, pp. 229-250, 2014.

[64] O. Fistikoglu and N. Harmacioglu, "Integration of GIS with USLE in assessment of soil erosion," Water Resources Management, vol. 16, pp. 447-476, 2002.

[65] C. A. A. Ciesiolka and C. W. Rose, "The measurement of soil erosion," in Soil Erosion at Multiple Scales: Principles and Methods for Assessing Causes and Impact, F. W. T. Penning de Vries, F. Agus, and J. Kerr, Eds., pp. 287-301, CAB International, Wallingford, UK, 1998.

[66] N. P. Owens and J. A. Collins, Soil Erosion and Sediment Redistribution in River Catchments: Measurement, Modelling and Management, CABI Publishing Series, Wallingford, UK, 2006.

[67] J. De Vente and J. Poesen, "Predicting soil erosion and sediment yield at the basin scale: scale issues and semiquantitative models," Earth-Science Reviews, vol. 71, pp. 95-125, 2005.

[68] A. G. Mayor, S. Bautista, and J. Bellot, "Scale-dependent variation in runoff and sediment yield in a semiarid Mediterranean catchment," Journal of Hydrology, vol. 397, pp. 128-135, 2011.

[69] P. Li, X. Mu, and J. Holden, "Comparison of soil erosion models used to study the Chinese Loess Plateau," EarthScience Reviews, vol. 170, pp. 17-30, 2017.

[70] P. Chuenchum, M. Xu, and W. Tang, "Estimation of soil erosion and sediment yield in the Lancang-Mekong river using the modified revised universal soil loss equation and GIS techniques," Water, vol. 12, no. 135, 2020.

[71] K. Ghosal and S. D. Bhattacharya, "A review of RUSLE model," Journal of the Indian Society of Remote Sensing, vol. 48, no. 4, pp. 689-707, 2020.

[72] Y. Farhan, D. Zregat, and F. Ibrahim, "Spatial estimation of soil erosion risk using RUSLE approach, RS, and GIS techniques: a case study of kufranja watershed, northern Jordan," Journal of Water Resource and Protection, vol. 5, pp. 1247-1261, 2013.

[73] K. Manjulavani, B. Prathyusha, and M. Ramesh, "Soil erosion and sediment yield modeling using remote sensing and GIS techniques," International Journal of Management and Applied Science, vol. 2, no. 10, pp. 59-63, 2016.

[74] A. A. Fenta, A. Tsunekawa, N. Haregeweyn et al., "Land susceptibility to water and wind erosion risks in the East Africa region," The Science of the Total Environment, vol. 703, 2020.

[75] P. Csáfordi, A. Pődör, J. Bug, and Z. Gribovszki, “Soil erosion analysis in a small forested catchment supported by ArcGIS model builder," Acta Silvatica et Lignaria Hungarica, vol. 8, pp. 39-55, 2012.

[76] E. H. Erdogan, G. Erpul, and I. Bayramin, "Use of USLE/GIS methodology for predicting soil loss in a semiarid agricultural watershed," Environmental Monitoring and Assessment, vol. 131, pp. 153-161, 2007.

[77] G. Ayalew and G. Y. Selassie, "Soil loss estimation for soil conservation planning using geographic information system in guang watershed, blue nile basin," Journal of Environment and Earth Science, vol. 5, no. 1, pp. 126-134, 2015.

[78] K. Chadli, "Estimation of soil loss using RUSLE model for Sebou watershed (Morocco)," Modeling Earth Systems and Environment, vol. 2, p. 51, 2016.

[79] S. H. Gelagay and S. A. Minale, "Soil loss estimation using GIS and Remote sensing techniques: a case of Koga watershed, Northwestern Ethiopia," International Soil and Water Conservation Research, vol. 4, pp. 126-136, 2016.

[80] N. G. Njiru, P. Kariuki, and K. Mwetu, "Modelling soil erosion for land management in ungauged golole catchment in marsabit county, Kenya," Open Journal of Soil Science, vol. 8, no. 11, pp. 277-302, 2018.

[81] G. Tesfaye and D. Tibebe, "Soil erosion modeling using GIS based RUSEL model in gilgel gibe-1 catchment, south west Ethiopia," International Journal of Environmental Sciences \& Natural Resources, vol. 15, no. 5, pp. 141-148, 2018.

[82] A. A. Beyene, "Soil erosion risk assessment in nashe dam reservoir using remote sensing, GIS and RUSLE model techniques in horro guduru wollega zone, oromia region, Ethiopia," Journal of Civil, Construction and Environmental Engineering, vol. 4, no. 1, pp. 1-18, 2019.

[83] M. C. Fayas, S. N. Abeysingha, S. G. K. Nirmanee, D. Samaratunga, and A. Mallawatantri, "HOSTED BYSoil loss estimation using rusle model to prioritize erosion control in KELANI river basin in Sri Lanka," International Soil and Water Conservation Research, vol. 7, no. 2, pp. 130-137, 2019.

[84] I. J. Amah, P. O. Aghamelu, V. O. Omonona, and M. I. Onwe, "A study of the dynamics of soil erosion using Rusle2 modelling and geospatial tool in edda-afikpo mesas, south eastern Nigeria," Pakistan Journal of Geriatrics, vol. 4, no. 2, pp. 56-71, 2020.

[85] S. Beskow, C. R. Mello, L. D. Norton, N. Curi, M. R. Viola, and J. C. Avanzi, "Soil erosion prediction in the Grande River 
Basin, Brazil using distributed modeling," Catena, Amsterdam, vol. 79, no. 1, pp. 49-59, 2009.

[86] K. Phinzi and N. S. Ngetar, "The assessment of water-borne erosion at catchment level using GIS-based RUSLE and remote sensing: a review international soil and water conservation research," vol. 7, no. 1, pp. 27-46, 2019.

[87] G. K. Renard and R. J. Freimund, "Using monthly precipitation data to estimate the R-factor in the revised USLE," Journal of Hydrology, vol. 157, pp. 287-306, 1994.

[88] H. Hurni, "Erosion-productivity-conservation systems in Ethiopia," in Proceedings of the 4th International Conference on Soil Conservation, pp. 654-674, Maracay, Venezuela, 1985.

[89] G. Singh, B. Ram, and S. Chandra, Soil Loss Prediction Research in India. Bulletin Nos. T-12/D-9, Central Soil and Water Conservation Research and Training Institute, Dehradun, India, 1981.

[90] R. Singh and V. S. Phadke, "Assessing soil loss by water erosion in Jamni River Basin, Bundelkhand region, India, adopting universal soil loss equation using GIS," Current Science, vol. 90, no. 10, pp. 1431-1435, 2006.

[91] R. Babu, K. Tejwani, M. Agrawal, and L. Bhusan, Rainfall Intensity Duration-Return Equation and Nomographs of India, CSWCRTI, ICAR, Dehradun, India, 1979.

[92] E. J. Roose, "Erosion et ruisellement en Afrique de I'ouest: vingt annies de measures empetites paecelles experimentales," Cyclo. ORSTOM, Adiopodoume, Ivory Coast, 1975.

[93] R. P. C. Morgan, Soil Erosion and Conservation, Longman Group, Essex, UK, 1986.

[94] N. I. Eltaif, M. A. Gharaibeh, F. Al-Zaitawi, and M. N. Alhamad, "Approximation of rainfall erosivity factors in northern Jordan," Pedosphere, vol. 20, no. 6, pp. 711-717, 2010.

[95] H. A. Kassam, T. H. Velthuizen, B. J. A. Mitchell, W. G. Fischer, and M. M. Shah, "Agro-ecological land resources assessment for agricultural development planning, a case study of kenya resources data base and land productivity. Technical Annex 2, Soil Erosion and Productivity," 1992.

[96] Harper, "Improving the accuracy of the universal soil loss equation in Thailand," in Proceedings of the Fifth International Conservation Conferences, Bangok, Thailand, 1987.

[97] P. Bols, "The iso-erodent map of java and Madura," Belgian Technical Assistance Project ATA, vol. 105, Soil Research Institute, Bogor, Indonesia, 1978.

[98] S. El-Swaify and E. Dangler, "Erodibilities of selected tropical soils in relation to structural and hydrologic parameters," in Soil Erosion Prediction and Control, G. Foster, Ed., pp. 105-114, Soil and Water Conservation Society, Ankeny, IO, USA, 1976.

[99] J. A. Baldock and P. N. Nelson, "Soil organic matter," in Handbook of Soil Science, pp. 655-690, CRC Press, Boca Raton, FL, USA, 2010.

[100] A. Merzoul, Relative Erodibility of Nine Selected Moroccan Soils Related to Their Physical and Chemical and Mineralogical Properties (Doctoral Dissertation), University of Minnesota, Minneapolis, MN, USA, 1985.

[101] S. Goldman and W. Wischmeier, Erosion and Sediment Control Handbook, McGraw-Hill, New York, NY, USA, 1986.

[102] M. J. M. Römkens, S. N. Prasad, and J. Poesen, "Soil erodibility and properties," Transactions of the XIII Congress of the International Soc. of Soil Sci.vol. 5, pp. 492-504, 1986.
[103] N. A. Sharply and R. J. Williams, EPIC-erosion/Productivity Impact Calculator I, Model Documentation, U.S. Department of Agriculture Technical Bulletin, Beltsville, MD, USA, 1990.

[104] M. J. M. Römkens, R. A. Young, J. W. A. Poesen, D. K. McCool, S. A. El-Swaify, and J. M. Bradford, "Chapter 3. Soil erodibility factor (K)," in Predicting Soil Erosion by Water: A Guide to Conservation Planning with the Revised Universal Soil Equation (RUSLE). Agriculture Handbook No. 703, K. G. Renard, G. R. Foster, G. A. Weesies, D. K. McCool, and D. C. Yoder, Eds., pp. 65-99, US Department of Agriculture, Washington, DC, USA, 1997.

[105] D. Torri, J. Poesen, and L. Borselli, "Predictability and uncertainty of the soil erodibility factor using a global dataset," Catena, vol. 31, pp. 1-22, 1997.

[106] P. Koirala, S. Thakuri, S. Joshi, and R. Chauhan, "Estimation of soil erosion in Nepal using a RUSLE modeling and geospatial tool," Geosciences, vol. 9, no. 147, 2019.

[107] V. Prasannakumar, R. Shiny, N. Geetha, and H. Vijith, "Spatial prediction of soil erosion risk by remote sensing, GIS and RUSLE approach: a case study of Siruvani river watershed in Attapady valley, Kerala, India," Environmental Earth Sciences, vol. 64, pp. 965-972, 2012.

[108] M. Kidane, A. Bezie, K. Nega, and T. Tolessa, "The impact of land use and land cover (LULC) dynamics on soil erosion and sediment yield in Ethiopia," Heliyon, vol. 5, 2019.

[109] I. Moore and F. Burch, "Physical basic of the length-slope factor in the universal soil loss equation," Soil Science Society of America Journal, vol. 50, pp. 1294-1298, 1986.

[110] D. McCool, L. Brown, G. Foster, and L. Mutchler, "Revised slope steepness factor for the universal soil loss equation," Transactions of the ASAE (American Society of Agricultural Engineers), vol. 30, pp. 1387-1396, 1987.

[111] P. Desmet and G. Govers, "A GIS-procedure for the automated calculation of the USLE LS-factor on topographically complex landscape units," Journal of Soil and Water Conservation, vol. 51, no. 5, pp. 427-433, 1996.

[112] H. Mitasova, J. Hofierka, M. Zlocha, and L. R. Iverson, "Modelling topographic potential for erosion and deposition using GIS," International Journal of Geographical Information Systems, vol. 10, no. 5, pp. 629-641, 1996.

[113] J. Mallick, Y. Alashker, A. S. Mohammad, M. Ahmed, and A. M. Hasan, "Risk assessment of soil erosion in semi-arid mountainous watershed in Saudi Arabia by RUSLE model coupled with remote sensing and GIS," Geocarto International, vol. 29, no. 8, pp. 915-940, 2014.

[114] A. Karaburun, "Estimation of C factor for soil erosion modeling using NDVI in Buyukcekmece watershed," Ozean Journal of Applied Sciences, vol. 3, no. 1, pp. 77-85, 2010.

[115] I. Gitas, "Multi temporal soil erosion risk assessment in N Chalkidiki Using a modified USLE raster model," EARSeL eProceedings, vol. 8, p. 1, 2009.

[116] B. A. Rhouma, T. Hermassi, and H. Habaieb, "Water erosion modeling in a mediterranean semi-arid catchment using USLE/GIS (el gouazine, Central Tunisia)," Journal of new sciences, vol. 50, no. 7, pp. 3071-3081, 2018.

[117] S. M. De Jong, "Derivation of vegetative variables from a Landsat TM image for modelling soil erosion," Earth Surface Processes, vol. 19, pp. 165-178, 1994.

[118] J. M. Van der Knijff, R. J. A. Jones, and L. Montanarella, Soil Erosion Risk Assessment in Europe, EUR $19044 \mathrm{EN}$. Office for Official Publications of the European Communities, Luxembourg, Luxembourg, 2000.

[119] J. M. Van der Knijff, R. J. A. Jones, and L. Montanarella, Soil Erosion Risk Assessment in Italy, European Soil Bureau, Joint 
Research Centre of the European Commission, 1999, https:// www.researchgate.net/profile/Luca_Montanarella/publication/ 254764323_Soil_Erosion_Risk_Assessment_in_Italy/links/ 02e7e5352d90f8e0f9000000/Soil-Erosion-Risk-Assessment-inItaly.pdf.

[120] E. Valor and V. Caselles, "Mapping land surface emissivity from NDVI. Application to European, African and South American areas," Remote Sensing of Environment, vol. 57, pp. 167-184, 1996.

[121] V. Durigon, D. Carvalho, M. Antunes, W. Almeid, and P. Oliveira, "Predicting soil erosion using RUSLE and NDVI time series from TM landsat 5," Pe squisa Agropec uária Brasileira, vol. 49, pp. 215-224, 2014.

[122] C. T. Haan, B. J. Barfield, and J. C. Hayes, Design Hydrology and Sedimentology for Small Catchments, Academic Press, New York, NY, USA, 1994.

[123] K. G. Renard, D. C. Yoder, D. T. Lightle, and S. M. Dabney, "Universal soil loss equation and revised universal soil loss equation," in Handbook of Erosion Modelling (137-167), R. P. C. Morgan and A. Nearing, Eds., Blackwell Publishing Ltd, Chichester, UK, 2011.

[124] K. G. Renard and G. R. Foster, "Soil conservation: principles of erosion by water," in Dryland Agriculture. Agronomy Monograph (155-176), H. E. Dregne and W. O. Willis, Eds., American Society of Agronomy, Madison, WI, USA, 1983.

[125] C. Alewell, P. Borrelli, K. Meusburger, and P. Panagos, "Using the USLE: chances, challenges and limitations of soil erosion modelling," International Soil and Water Conservation Research, vol. 7, pp. 203-225, 2019.

[126] K. Hurni, G. Zeleke, M. Kassie et al., "Economics of land degradation (ELD) Ethiopia case study soil degradation and sustainable land management in the rainfed agricultural areas of ethiopia: an assessment of the economic implications," 2015.

[127] S. H. Gelagay, "RUSLE and SDR model based sediment yield assessment in a GIS and remote sensing environment; a case study of koga watershed, upper blue nile basin, Ethiopia," Hydrology: Current Research, vol. 7, no. 2, pp. 1-10, 2016.

[128] K. B. Kogo, L. Kumar, and R. Koech, "Impact of land use/ cover changes on soil erosion in western Kenya," Sustainability, vol. 12, no. 9740, 2020.

[129] A. K. Luvai, J. P. O. Obiero, and C. T. Omuto, “Assessment of soil loss in a typical ungauged dam catchment using RUSLE model (Maruba dam, Kenya)," Journal of Environment and Earth Science, vol. 11, no. 16, pp. 56-68, 2021.

[130] C. Wener, Soil Conservation in Kenya, Ministry of Agriculture, Soil Conservation Extension Unit, Nairobi, Kenya, 1981.

[131] A. Lufafa, M. M. Tenywa, M. Isabirye, M. J. G. Majaliwa, and P. L. Woomer, "Prediction of soil erosion in a Lake Victoria basin catchment using a GIS-based Universal Soil Loss model," Agricultural Systems, vol. 76, no. 3, pp. 883-894, 2003.

[132] B. J. Fu, W. W. Zhao, L. D. Chen et al., "Assessment of soil erosion at large watershed scale using RUSLE and GIS: a case study in the Loess Plateau of China," Land Degradation \& Development, vol. 16, no. 1, pp. 73-85, 2005.

[133] M. Napoli, S. Cecchi, S. Orlandini, G. Muganai, and C. A. Zanchi, "Simulation of field-measured soil loss in Mediterranean hilly areas (Chianti, Italy) with RUSLE," Catena, vol. 145, pp. 246-256, 2017. 